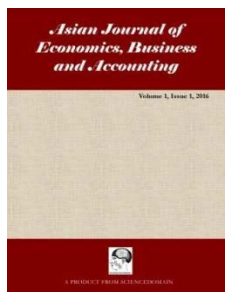

\title{
The Role of Microfinance Banks on Employment Generation in the Grassroots: Evidence from Karu Local Government Area of Nasarawa State, Nigeria
}

\author{
U. Adama, Joseph ${ }^{1}$, U. Duru, Innocent ${ }^{2^{*}}$ and O. Diyoke, Kenneth ${ }^{3}$ \\ ${ }^{1}$ Department of Economics, Landmark University, Omu-Aran, Kwara State, Nigeria. \\ ${ }^{2}$ Department of Economics, Salem University, Lokoja, Kogi State, Nigeria. \\ ${ }^{3}$ Department of Economics, Nile University of Nigeria, Abuja, Nigeria.
}

\begin{abstract}
Authors' contributions
This work was carried out in collaboration among all authors. Author UAJ wrote the methodology of the study. Author UDI designed the study, interpreted and analysed the results, wrote the protocol, managed the literature searches, wrote the literature review and wrote the first, revised and final draft of the manuscript. Author ODK performed the statistical analysis of the study. All authors read and approved the final manuscript.

Article Information

DOI: $10.9734 / A J E B A / 2017 / 35325$

(1) Emilija Miteva-Kacarski, Faculty of Economics, Goce Delcev University -Stip, Republic of Macedonia.

(1) S. Vasantha, Vels University, India.

(2) T. A. Odetayo, Osun State Polytechnic, Nigeria. (3) Abeh Aondoseer, Federal Polytechnic, Nigeria. (4) Gazia Sayed, IES Management College and Research Centre, India. Complete Peer review History: http://www.sciencedomain.org/review-history/20626
\end{abstract}

Original Research Article

Received $7^{\text {th }}$ July 2017 Accepted 11 ${ }^{\text {th }}$ August 2017 Published 23 ${ }^{\text {rd }}$ August 2017

\begin{abstract}
This study investigated the role of Microfinance Banks on employment generation in Karu Local Government Area (L.G.A) of Nasarawa State, Nigeria. The aim is to ascertain the extent to which microfinance banks have discharged their responsibilities of transforming the rural areas and making financial services accessible to a large segment of the potentially productive Nigerian population which otherwise would have little or no access to financial services. The study adopted a survey research design. The instrument for data collection was a structured questionnaire. One Hundred and Twenty customers of MFBs and two MFBs were randomly and purposively selected for the study. A total of 120 copies of the questionnaires were administered out of which 100 copies were properly completed and retrieved while 20 copies were not retrieved. Descriptive statistics
\end{abstract}


was employed to analyze data for the study; the tools are simple percentage and frequency distribution. The study showed among others that creation of jobs was the greatest effect of financial intermediation of MFBs in the Grassroots. However, it also showed that lack of entrepreneurial skills was the major problem confronting the MFBs in the area financial intermediation for employment generation in the grassroots. The study therefore recommends among others that The Central Bank of Nigeria should evolve a credit policy that ensures that a certain percentage of the loan portfolio of the MFBs go for the transformation of the grassroots. Also, government should through the CBN, regulate, monitor the activities of MFBs, and redress the constraints affecting them in the area of financial intermediation for employment generation through favourable credit policy which can lead to entrepreneurial development in the rural areas. The CBN should ensure that loans advanced by MFBs to the grassroots are serviced at a single digit interest rate in order not to deter people with genuine business ideas.

Keywords: Microfinance Banks; employment generation and grassroots.

\section{INTRODUCTION}

One of the key objectives of the Transformation Agenda, a home-grown medium term development framework to move the Nigerian economy to a vibrant growth path and launch her into the league of advanced economies by year 2020 as enunciated in the Vision 20:2020 of the Federal Republic of Nigeria is to create decent jobs in sufficient quantities to resolve the protracted problem of unemployment and reduce poverty.

Unemployment is one of the greatest challenges facing sub-Saharan African countries and Nigeria in particular. The problem of unemployment has been of great concern to scholars in development economics, policy makers and international development partners. It is the magnitude of this problem that the Sustainable Development Goals set by the United Nations in 2015 , with a vision of a fairer, more prosperous, peaceful and sustainable world in which no one is left behind was dedicated to decent work and economic development and to end poverty for all in the year 2030 .

The grassroots play important roles in the development of the Nigerian economy. They are dominated by almost 80 percent of the world's extreme poor who depends on agriculture for livelihood FAO [1]. It is a major source of agricultural commodities for matching urban demand. Agriculture is one of the core sector of the Nigerian economy and plays pivotal role in the growth and development of the economy. The role of the grass root people in agriculture, which is mainly grass root based, and the magnitude of poverty and unemployment in the economy makes it pivotal for microfinance interventions. The grassroots will therefore be strategic to the attainment of the Green Initiative of the Federal Government of Nigeria aimed at revamping its recessed economy.

Unemployment creates instability and this affects economic growth. As was advocated by Simpasa, Shimeles and Salami [2], poverty reduction has been slowed down by weak job creation and could jeopardize the political and social stability of the African continent as demonstrated by events in North Africa. In the light of the above, any programme aimed at ending poverty and unemployment under the current economic slowdown in Nigeria must begin at the grassroots, which is where most of the poor live. The panacea for robust economic growth to be attained is that well focused programmes to reduce poverty by empowering the people through increasing their access to factors of production, especially, credit, must be put in place CBN [3].

Microfinance banks (MFBs) play important roles in the economic growth and development of any government because of their potentials in poverty reduction, wealth creation and employment generation. Through their services, the capacity of the people in the grassroots who are traditionally not served by the conventional banks due to poor infrastructures, small number of people and the general poverty of the grassroots could be enhanced to enable them engage in economic activities, increase household incomes and increase employment opportunities thereby serving as critical agents of change in line with the change mantra of the current administration. A study conducted by Adebusuyi, Sere-Ejembi, Nwolisa and Ugoji [4] stated that financial services provided to the economically active poor 
by MFBs drive economic activities and employment generation by contributing to the commencement or expansion of income generating ventures.

Many programmes targeted at poverty reduction, employment generation, and improvement in the flow of financial services to the people in the grassroots, were initiated by successive governments in Nigeria since independence in 1960. The programmes were the Agricultural Credit Guarantee Scheme (ACGS), the Rural Banking Programme, Community Banks, National Directorate of Employment (NDE), National Poverty Eradication Programme (NAPEP), Peoples Bank of Nigeria (PBN), Nigerian Agricultural Cooperative Bank (NACB), Family Economic Advancement Programme (FEAP), and Nigerian Agricultural, Cooperative and Rural Development Bank (NACRDB) Adebusuyi et al. [4]. As stated by Adebusuyi et al. [4], the Federal Government of Nigeria merged the FEAP with PBN and NACB to form the NACRDB in the year 2000 whose name later metamorphed to the Bank of Agriculture (BOA) to improve the provision of credit to the agricultural sector. Programmes such as the Rural Banking Programme, NAPEP and NDE with grassroots focus failed to empower the grass root people in terms of meaningful employment generation and poverty reduction despite the obvious need for economic growth and development with the grassroots as engine of growth.

Some previous studies have examined the role of microfinance on grassroot development. Prominent among these studies are Oluyombo [5], and Opue, Anagbogu and Udousoro [6]. This study is different from others because the focus is to examine the role of MFBs on employment generation in the grassroots. The questions that come to mind are: what is the role of MFBs on employment generation in the grassroots? What are the problems hindering the MFBs in the area of financial intermediation for employment generation in the grassroots? It is on the basis of this that the main thrust of this paper is: i) to examine the role of MFBs on employment generation in the grassroots. In addition it will: ii) identify the problems hindering the MFBs in the area of financial intermediation for employment generation in the grassroots. The paper is organized into five sections. Following this introduction, section two dwells on the literature review. Section three focuses on the methodology. Data presentation, analysis and discussions are in section four while section five looks at the recommendations and concludes the paper.

\section{LITERATURE REVIEW}

\subsection{The Role of Microfinance Banks on Employment Generation in the Grassroots}

Some studies have been undertaken on the role of microfinance on employment generation in the grassroots with varying results and submissions. For instance, Kazi and Leonard [7], investigated the relationship among microfinance, poverty and youth unemployment in Nigeria with a view to finding out if the microfinance programmes initiated in Nigeria are effective in curbing the magnitude of unemployment and poverty in Nigeria. They also investigated the Grameen Bank's microfinance model developed by Yunus for comparison. Employing the Ordinary Least Square methodology, their findings revealed that the microfinance programmes initiated in Nigeria are not effective in addressing its poverty and unemployment. Their findings also showed that the microfinance model initiated by Yunus in Bangladesh is most effective for addressing the problems of poverty and unemployment which is lacking in the Nigerian microfinance programmes.

Okafor, Ezeaku and Ugwuegbe [8], examined the impact of microcredit on poverty reduction in Nigeria for the periods 1999 to 2014. Using the error correction model (ECM), the results revealed that microcredit has negative and nonsignificant impact on poverty reduction in Nigeria. Based on the findings, they concluded that microcredit have not played any significant role in alleviating poverty in Nigeria. Abdullah- AlMamun, Wahab, and Malarvizhi [9], in their research, investigated how participation in Amanah Ikhtiar Malaysia's (AIM) microcredit programme affects employment rate of hardcore poor clients household and community in Peninsular Malaysia through the use of descriptive statistics. Stratified random sampling method and a cross sectional design was employed in selecting the sample used in the study. Their results revealed that that participation in AIM's microcredit program increases employment generating opportunities at household and community level.

The study of Alani and Sani [10], examined the impact of MFBs on rural dwellers in Kogi state. 
Employing descriptive statistics on a sample of five MFBs (Idah MFB, Gains MFB, Ajeko MFB, Unyongba MFB and Odu MFB), obtained through judgmental sampling process, their results showed that MFBs have significant impact on the rural dwellers in Kogi State through savings mobilization for financial intermediation and provision of employment opportunities. The implication of their results is that MFBs have the potential of improving the productive and economic capacities of the active poor in the rural communities of Kogi State.

Onwuka, Udeh, and Nwannebuike [11], investigated the impact of rural credit facilities of MFBs on poverty alleviation in Nigeria for the periods 2005 to 2012 by employing Multinomial Logistic Regression Model and descriptive statistics on a sample of two hundred and seventy rural MFBs and household respondents from Anambra State, Enugu State and Imo State obtained through a multi-stage sampling process. Their study revealed that deposits mobilized from rural communities by MFBs were siphoned out of the communities by way of fixed deposits with commercial banks usually located outside the communities, thereby defeating the sole idea of financial intermediation within the communities. In light of their findings, they concluded that in spite of modest impact of rural credit facilities from MFBs with respect to deposit mobilization, wide areas for improvement still exist in relation to participation of women in credit facilities, among others.

Adopting the descriptive survey research design, Akosile and Ajayi [12], investigated to know if the credit and financial facilities advanced by the Microfinance Institutions (MFIs), particularly the MFBs and Cooperative Investment and Credit Societies (CICSs) to the informal sector and Micro, Small and Medium Enterprises (MSMEs) are properly utilized to reduce poverty and improve economic development. They discovered that credit and financial services provided by the MFBs and CICSs enable the poor and low income group and MSMEs to embark in economic activities that improves their income, creates wealth for them and make them self-reliance and thereby reduce poverty.

Employing descriptive research design, Regression analysis and Analysis of Variance (ANOVA) methodologies, Jegede, Kehinde and Akinlabi [13], examined empirically the relationship between microfinance loan disbursement and poverty alleviation in Nigeria. Data were sought through questionnaires and analysed through the help of descriptive statistical techniques such as total score and percentages, while chi-square test was used to test the formulated hypotheses. The results showed that there is a significant difference between those people who used microfinance institutions and those who do not use them. Furthermore, microfinance institutions was pivotal in alleviating poverty through enhanced income and changing economic status of those who patronize them. In the light of these findings, they concluded that MFIs is indeed a potent strategy of poverty reduction and a veritable tool for circulating credit to the poor.

Qazi, Aurangzeb and Hussain [14], examined the effectiveness of Microfinance in generating opportunities and alleviating poverty in Pakistan. The long time impact of microfinance programmes on recipients, their accessibility to health services, and education for their children, and the improvement in their families' consumption levels, and increment in their income level was also investigated. Employing principally existing literatures and data relevant to the subject matter of the study, through in-depth interviews and hybrid questionnaire, they discovered that microfinance has created opportunities in terms of employment generation, improvement in income, generation of more economic activities and women empowerment. On the other hand, no empirical results about alleviation of poverty was found.

Oluyombo [5], analysed the pattern and the value of loans, advances and credit disbursed to people in different segments of the rural economy of Nigeria from 1992 to 2006. Employing principally existing literatures and data from the Central Bank of Nigeria (CBN) relevant to the subject matter of the study, through a quantitative approach, the results showed a major downward pattern in the monetary worth of credits to rural people compared to the deposits received from them. This is manifested in a net outflow of finance from the rural poor thereby compromising the sustainable development of the rural areas.

Adopting the Ordinary Least Square methodology and the descriptive statistical technique of percentages, Opue, Anagbogu and 
Udousoro [6], investigated the impact of MFBs on the socioeconomic development of rural communities in Cross River State. Employing principally existing literatures and data relevant to the subject matter of the study, through structured questionnaires, they discovered that CBN credit policy has a significant effect on the supply of credit to institutional borrowers such as micro-finance banks; and that microfinance banks exert no significant influence on the socio-economic development of rural communities in Cross River State.

A number of previous studies relating to MFBs, poverty reduction, poverty alleviation, rural dwellers, socioeconomic development of rural communities and economic development have been conducted in Nigeria. Research regarding the role of MFBs on employment generation in the grassroots in Nigeria is inadequate. As a result, very limited research has been accomplished with reference to Nigeria. There is an increasing body of literature investigating the role of MFBs on employment generation in the grassroots of countries but as far as Nigeria is concerned, no thought-provoking effort has been made so far to empirically appreciate the role of MFBs on employment generation with emphasis in the grassroots. This study is meant to bridge the gap in the literature as far as the role of MFBs on employment generation in the grassroots is concerned.

\section{METHODOLOGY}

The survey research design was employed for this study. The MFBs in Karu L.G.A. and their customers constitute the population of the study. Data used in the study were collected through structured questionnaires. The questionnaires were designed for both the MFBs and their customers. The study utilised descriptive statistical techniques such as percentages, tables and charts to show the relevant data. The Microfinance Banks in Nasarawa State are presented in Table 1.

Josad Microfinance Bank Limited and Sky-line Microfinance Limited were judgmentally selected from Karu L.G.A. for this study. One Hundred and twenty customers of the two Microfinance Banks were selected randomly and administered with the questionnaire. Only one hundred customers of the selected MFBs filled and returned the questionnaire.
Table 1. Licensed Microfinance Banks (MFBs) in Nasarawa State

\begin{tabular}{|c|c|c|c|}
\hline S/No & Name & State & $\begin{array}{l}\text { Local } \\
\text { Government } \\
\text { Area } \\
\text { (L.G.A.) }\end{array}$ \\
\hline 1 & $\begin{array}{l}\text { Ada } \\
\text { Microfinance } \\
\text { Bank Limited }\end{array}$ & Nasarawa & Kokona \\
\hline 2 & $\begin{array}{l}\text { Amba } \\
\text { Microfinance } \\
\text { Bank Limited }\end{array}$ & Nasarawa & Lafia \\
\hline 3 & $\begin{array}{l}\text { FEDPOLY } \\
\text { Nassarawa } \\
\text { Microfinance } \\
\text { Bank Limited }\end{array}$ & Nasarawa & Nasarawa \\
\hline 4 & $\begin{array}{l}\text { Josad } \\
\text { Microfinance } \\
\text { Bank Limited }\end{array}$ & Nasarawa & Karu \\
\hline 5 & $\begin{array}{l}\text { Keffi } \\
\text { Microfinance } \\
\text { Bank Limited }\end{array}$ & Nasarawa & Keffi \\
\hline 6 & $\begin{array}{l}\text { Nasarawa } \\
\text { Microfinance } \\
\text { Bank Limited }\end{array}$ & Nasarawa & Nasarawa \\
\hline 7 & $\begin{array}{l}\text { Sky-line } \\
\text { Microfinance } \\
\text { Bank Limited }\end{array}$ & Nasarawa & Karu \\
\hline 8 & $\begin{array}{l}\text { Waila } \\
\text { Microfinance } \\
\text { Bank Limited }\end{array}$ & Nasarawa & Keffi \\
\hline
\end{tabular}

\section{DATA PRESENTATION, ANALYSIS AND DISCUSSION}

The result in Table 2 showed the demographic characteristics of the respondents. It revealed that out of the 100 sample size of the respondents, 5 or $5 \%$ of them belong to the age range of less than 20 years, 30 or $30 \%$ of them are in the age range of $21-30$ years, 25 or $25 \%$ of them are in the age range of $31-40$ years, 20 or $20 \%$ of them are in the age range of $41-50$ years, 10 or $10 \%$ of them are in the age range of $51-60$ years while only 10 or $10 \%$ of them belong to the age range of 61 years and above. In terms of their gender, 60 or $60 \%$ are male while 40 or $40 \%$ are female. Looking at the marital status of the respondents, 0 or $0 \%$ of them were never married, 15 or $15 \%$ of them were engaged to be married, 40 or $40 \%$ of them were married, 15 or $15 \%$ of them were separated, 10 or $10 \%$ of them were widowed while 20 or $20 \%$ of them were single. In terms of their formal education, 15 or 
$15 \%$ of them had Primary School education, 60 or $60 \%$ of them had Secondary School education, 15 or $15 \%$ of them had Technical and Vocational education while 10 or $10 \%$ of them had University or higher education. With reference to their informal education, 30 or $30 \%$ of them had Vocational Training, 35 or $35 \%$ of them had Job Training, 20 or $20 \%$ of them had Special Training while 15 or $15 \%$ of them had other Trainings. Looking at the occupation of the respondents, 20 or $20 \%$ of them were farmers, 25 or $25 \%$ of them were artisans, 50 or $50 \%$ of them were engaged in business, 5 or $5 \%$ of them were manufacturers while 0 or $0 \%$ of them were in other occupations.

The result in Table 3 showed the constraints confronting MFBs in the area of financial intermediation for employment generation in Karu L.G.A. As a result, eight constraints were identified and built into the questionnaire and the respondents were asked to indicate the option that suits their opinion. A 5-point likert type scale from " $1=$ least important" to " $5=$ most important" was used to measure how important certain constraints mentioned in the questionnaire were. The result showed that lack of entrepreneurial skills was the greatest constraints facing MFBs in the area of financial intermediation in Karu L.G.A. It has the highest frequency of 275 with a mean score of 2.75 , this is followed by limited access to Development Finance loans with a mean score of 2.35 , then government regulations with a mean score of 2.21 and investment levels and high cost of finance and with a mean score of 2.15 and 2.14 respectively.

Table 2. Demographic characteristics of respondents

\begin{tabular}{llll}
\hline Variable & Items & Frequency & Percentage (\%) \\
\hline Age & Less than 20 & 05 & 05 \\
& $21-30$ & 30 & 30 \\
& $31-40$ & 25 & 25 \\
& $41-50$ & 20 & 20 \\
Gender & $51-60$ & 10 & 10 \\
& 61 and above & 10 & 10 \\
Marital status & Total & 100 & 100 \\
& Male & 60 & 60 \\
& Female & 40 & 40 \\
& Total & 100 & 100 \\
& Married & 40 & 40 \\
& Single & 20 & 20 \\
& Widowed & 10 & 10 \\
& Separated & 15 & 15 \\
& Never married & 0 & 0 \\
& Engaged to be married & 15 & 15 \\
& Total & 100 & 100 \\
& Primary school & 15 & 15 \\
& Secondary school & 60 & 60 \\
& Technical \& Vocational & 15 & 15 \\
Informal education & & & \\
& education & 10 & 10 \\
& University or higher & & \\
& education & 100 & 100 \\
& Total & 30 & 30 \\
& Vocational training & 35 & 35 \\
Occupation & Job training & 20 & 15 \\
& Special training & 15 & 100 \\
& Others & 100 & 20 \\
& Total & 20 & 25 \\
& Farming & 25 & 50 \\
& Artisan & 50 & 05 \\
& Business & 05 & 0 \\
& Manufacturer & 100 & 100 \\
\hline & Others & 2017 &
\end{tabular}


In the Table 4, a scale was developed to examine the effect of financial intermediation of MFBs in Karu L.G.A. The effects were derived as a result of in-depth interviews and participant observation. The scale ranges from 1 to 5 , where " $1=$ least important" and " $1=$ most important". The effects of financial intermediation of MFBs to a great extent in the study area were creation of jobs with a mean score of 2.75 , improved productivity with a mean score of 2.39 , access to finance with a mean score of 2.55 , savings mobilization with a mean score of 2.32 and working capital support with a mean score of
2.60 respectively. The result showed that creation of jobs was the greatest effect of financial intermediation of MFBs in the Grassroots.

Table 5 showed that $32 \%$ of the respondents started their business with personal savings, $28 \%$ of them started their business with contribution from family and friends, $30 \%$ said that they started their business with credit from MFBs while $10 \%$ of them started their business with inherited wealth.

Table 3. Constraints affecting the MFBs in the area of financial intermediation for employment generation in the grassroots

\begin{tabular}{llllllll}
\hline Constraint & $\begin{array}{l}\text { Most } \\
\text { important } \\
\text { (X1) }\end{array}$ & $\begin{array}{l}\text { Important } \\
(\mathbf{X})\end{array}$ & $\begin{array}{l}\text { Neutral } \\
(\mathbf{X})\end{array}$ & $\begin{array}{l}\text { Less } \\
\text { important } \\
\text { (X4) }\end{array}$ & $\begin{array}{l}\text { Least } \\
\text { important } \\
\text { (X5) }\end{array}$ & Sum & Mean \\
\hline $\begin{array}{l}\text { Investment } \\
\text { levels }\end{array}$ & 30 & 90 & 30 & 40 & 25 & 215 & 2.15 \\
$\begin{array}{l}\text { High cost of } \\
\text { finance }\end{array}$ & 37 & 60 & 45 & 72 & 0 & 214 & 2.14 \\
$\begin{array}{l}\text { Cultural attitude } \\
\text { towards savings }\end{array}$ & 37 & 86 & 30 & 60 & 0 & 213 & 2.13 \\
$\begin{array}{l}\text { Collateral } \\
\text { requirement }\end{array}$ & 45 & 60 & 45 & 20 & 5 & 175 & 1.75 \\
$\begin{array}{l}\text { Limited access } \\
\text { to development } \\
\text { finance loans }\end{array}$ & 33 & 46 & 75 & 56 & 25 & 235 & 2.35 \\
$\begin{array}{l}\text { Government } \\
\text { regulations }\end{array}$ & 37 & 60 & 36 & 68 & 20 & 221 & 2.21 \\
$\begin{array}{l}\text { Lack of } \\
\text { entrepreneurial } \\
\text { skills }\end{array}$ & 10 & 90 & 45 & 80 & 50 & 275 & 2.75 \\
$\begin{array}{l}\text { Feasibility of } \\
\text { business }\end{array}$ & 40 & 70 & 45 & 40 & 0 & 195 & 1.95 \\
\hline
\end{tabular}

Table 4. Effects of financial intermediation of microfinance banks in the grassroots

\begin{tabular}{|c|c|c|c|c|c|c|c|}
\hline Effect & $\begin{array}{l}\text { Most } \\
\text { important } \\
\text { (X1) }\end{array}$ & $\begin{array}{l}\text { Important } \\
\text { (X2) }\end{array}$ & $\begin{array}{l}\text { Neutral } \\
\text { (X3) }\end{array}$ & $\begin{array}{l}\text { Less } \\
\text { important } \\
(\mathrm{X} 4)\end{array}$ & $\begin{array}{l}\text { Least } \\
\text { important } \\
\text { (X5) }\end{array}$ & Sum & Mean \\
\hline Create jobs & 15 & 80 & 45 & 60 & 75 & 275 & 2.75 \\
\hline $\begin{array}{l}\text { Improved } \\
\text { productivity }\end{array}$ & 30 & 48 & 75 & 56 & 30 & 239 & 2.39 \\
\hline $\begin{array}{l}\text { Access to } \\
\text { finance }\end{array}$ & 20 & 60 & 93 & 52 & 30 & 255 & 2.55 \\
\hline $\begin{array}{l}\text { Savings } \\
\text { mobilisation }\end{array}$ & 21 & 92 & 39 & 80 & 0 & 232 & 2.32 \\
\hline $\begin{array}{l}\text { Working capital } \\
\text { support }\end{array}$ & 11 & 92 & 60 & 72 & 25 & 260 & 2.60 \\
\hline
\end{tabular}




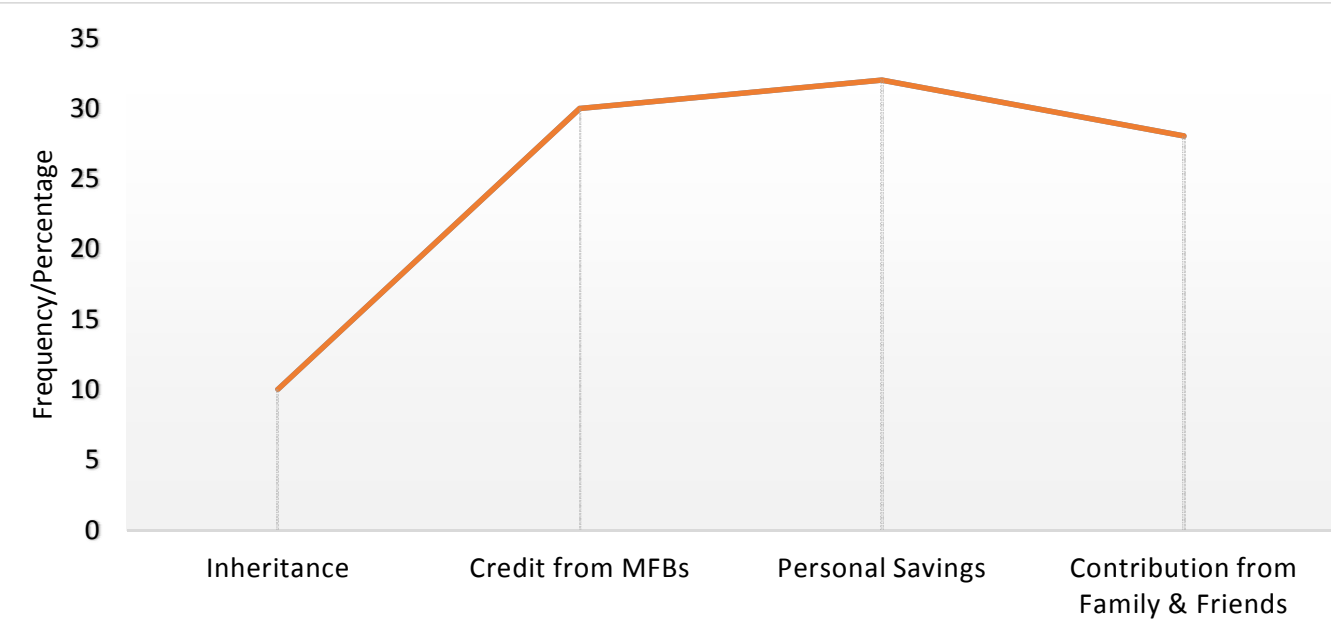

Source of Finance

- Frequency Percentage (\%)

Fig. 1. Percentage distribution of respondents based on source of finance to start their business

Table 5. Source of finance to start business

\begin{tabular}{lll}
\hline Option & Frequency & $\begin{array}{l}\text { Percentage } \\
(\%)\end{array}$ \\
\hline Inheritance & 10 & 10 \\
Credit from MFBs & 30 & 30 \\
Personal savings & 32 & 32 \\
Contribution from & 28 & 28 \\
Family and friends & 100 & 100 \\
Total & 100 \\
\hline \multicolumn{2}{c}{ Source: Field survey, 2017 }
\end{tabular}

\section{CONCLUSION AND RECOMMENDA- TIONS}

It is evident from the foregoing that MFBs if adequately promoted can serve as a driving force for job creation in the grassroots thereby enhancing the implementation of the Sustainable Development Goals (SDGs). Although, MFBs have been a source of finance for people in the grassroots, it has performed below expectation in terms of making financial services accessible to a large segment of the potentially productive Nigerian population which otherwise would have little or no access to financial services. This was evident in the result that showed that majority of the people in the grassroots started their business outfits with personal savings. Therefore, there is little to jubilate about since their aim of transforming the grassroots is yet to come to fruition. The results from this study revealed that the greatest effect of MFBs financial intermediation in the grassroots was creation of jobs. This result finds an advocate in Akosile and Ajayi [12] and Qazi, Aurangzeb and Hussain [14]. The result is contrary to the submissions of Kazi and Leonard [7]. The results also revealed that lack of entrepreneurial skills was the greatest constraint affecting the MFBs in the area of financial intermediation for employment generation in the grassroots. The results also showed that limited access to development finance loans was another major constraint affecting the MFBs in the area of financial intermediation for employment generation in the grassroots. Based on the findings of this study, the following recommendations are proposed:

a. The Central Bank of Nigeria (CBN) should evolve a credit policy that ensures that a certain percentage of the loan portfolio of the MFBs go for the transformation of the grassroots.

b. Government should through the CBN, regulate, monitor the activities of MFBs, and redress the constraints affecting them in the area of financial intermediation for employment generation through favourable credit policy which can lead to entrepreneurial development in the rural areas.

c. The CBN should ensure that loans advanced by MFBs to the grassroots are 
serviced at a single digit interest rate in order not to deter people with genuine business ideas.

d. MFBs should train the rural dwellers on entrepreneurship and credit utilization with a view to equipping them with the necessary entrepreneurial skills to establish, manage, sustain and expand their business outfits.

\section{COMPETING INTERESTS}

Authors have declared that no competing interests exist.

\section{REFERENCES}

1. Food and Agriculture Organization of the United Nations. Food and Agriculture Organization and the Seventeen Sustainable Development Goals. Rome: Food and Agriculture Organization of the United Nations; 2015.

2. Simpasa AM, Shimeles A, Salami AO. Employment effects of multilateral development bank support: The case of the African Development Bank. African Economic Research Consortium (AERC) Working Paper, No. 221. 2015;1-28.

3. Central Bank of Nigeria. Microfinance policy, regulatory and supervisory framework for Nigeria. Abuja, Nigeria: Central Bank of Nigeria, Abuja; 2005.

4. Adebusuyi B, Sere-Ejembi A, Nwolisa C, Ugoji C. Towards a sustainable microfinance development in Nigeria. Abuja, Nigeria: Research Department, Central Bank of Nigeria, Abuja, Occasional Paper No. 37; 2008.

5. Oluyombo OO. Assessment of rural sustainable development by Microfinance Banks in Nigeria. IESD Phd Conference: Energy and Sustainable Development. Leicester: Institute of Energy and Sustainable Development. 2010;126-137. Available:https://ssrn.com/abstract=288533 $\underline{4}$

(Accessed on 24/01/17)
6. Opue JA, Anagbogu GE, Udousoro AU. The role of Microfinance Banks in the socio-economic development of rural communities in Cross River State. Global Journal of Applied Sciences, Management and Social Sciences. 2011;1(1):1-25.

7. Kazi MH, Leonard JE. Microfinance, poverty and youth unemployment in Nigeria: A review. Global Journal of Human Social Science, Sociology, Economics, and Political Science. 2012; 12(13):44-59.

8. Okafor IG, Ezeaku HC, Ugwuegbe S. Microcredit and poverty reduction: A case of Nigeria. International Journal of Multidisciplinary Research and Information. 2016;2(4):319-325.

9. Abdullah-Al-Mamun, Wahab SA, Malarvizhi CA. Examining the effect of microcredit on employment in Peninsular Malaysia. Journal of Sustainable Development. 2011;4(2):174-183.

10. Alani GO, Sani J. Effects of Microfinance Banks on the Rural Dwellers in Kogi State, Nigeria. International Journal of Public Administration and Management Research. 2014;2(2):66-79.

11. Onwuka IO, Udeh Nwannebuike S. Impact of rural credit facilities of Microfinance Banks on poverty alleviation: The Nigerian Experience. European Scientific Journal. 2015;11(28):481-512.

12. Akosile Al, Ajayi OA. The impact of microfinance institutions on poverty reduction in Nigeria. European Journal of Business and Management. 2014;6(35): 1-7.

13. Jegede C, Kehinde J, Akinlabi B. Impact of microfinance on poverty alleviation in Nigeria: An empirical investigation. European Journal of Humanities and Social Sciences. 2011;97-111.

14. Qazi S, Aurangzeb, Hussain S. Microfinance: Effective in generating opportunities and mitigating poverty in Pakistan. Global Advanced Research Journal of Management and Business Studies. 2015;4(9):357-362.

(c) 2017 Joseph et al.; This is an Open Access article distributed under the terms of the Creative Commons Attribution License (http://creativecommons.org/licenses/by/4.0), which permits unrestricted use, distribution, and reproduction in any medium, provided the original work is properly cited.

Peer-review history:

The peer review history for this paper can be accessed here: http://sciencedomain.org/review-history/20626 